\title{
Lysslottet i Luster
}

I 1896 ble det ved kongelig resolusjon besluttet «at St. Jørgens hospital for spedalske skulde gaa over til et hospital for fattige tæringssyge i Bergens stift». Innerst i Sogn fant man den perfekte beliggenhet - «Mod nord og vest er sanatoriet beskyttet af en sammenhængende fjeldkjæde, mod syd og øst har man en prægtig udsigt over Sognefjorden og fjeldene, som bekranser den. Man ser lige ind i Jotunheimen med de sneklædte tinder». Elektrisitet var en forutsetning - et eget kraftverk sørget for at 500 lyspærer kunne ses fra bygda lsom ikke fikk strøm før i 1915). Sanatoriet ble innviet i 1902. Under gjengis deler av overlege Klaus Hansens åpningstale, med en gjennomgang av kostnadene for et anlegg med blant annet elektrisk taubane, hovedbygning, vaskeri, stall og grisehus (Tidsskr Nor Lægeforen 1902; 22: 1107-17). Men sykdomspanoramaet endres, og samfunnets behov med det. Sanatoriet ble nedlagt i 1950-årene. For et par år siden var anlegget til salgs for én krone...

\section{Lyster tuberkulosesanatorium.}

(Af E. Grundt, sanatoriets direktør).

Jeg bringer alle dem, som ved sit arbeide har bidraget til dette anlægs fuldførelse komiteens bedste tak. En tak til alle de arbeidere, som trolig har arbeidet ved dag som ved nat, naar d e $\mathrm{t}$ var nødvendigt, stundom under svære veirforhold som igaar, stadig under de uheldige forhold i retning af husly og forpleining, som arbeidet her tilfjelds med nødvendighet har medført. Anlægget kostet foruden grunden og inventar ca. 630000 kroner, heraf kommer omtrent 130000 paa anlæg, som er nødvendiggjort af stedets beliggenhed saa høit tilfjelds og saa langt inde i fjorden. Selve sanatoriebygningen og de nødvendige udhuse med centralopvarmning, elektrisk lys o. s. v. koster 500000 kroner.

(...)

En farsot som tuberkulosen er en ulykke for det hele samfund, den berører os alle mere eller mindre direkte. I første række rammer den alle dem, som selv angribes af sygdommen. Ved oprettelsen af sanatorier opfylder samfundet sin pligt mod disse ulykkelige, den pligt at byde al den hjælp til helbredelse, som videnskaben for tiden formaar. Den gamle haabløshed ligeoverfor tuberkulosen er vi kommen over. Vi har visheden for, at helbredelse er mulig. Hvor mange der kan helbredes, afhænger for en væsentlig del af os selv, det vil sige af patienten og af lægen. Jo tættere vi kan følge fienden i hælene, jo tidligere man her paa sanatorierne kan tage sig af den syge, efterat sygdommen har slaat kloen i ham, des sikrere er vi paa seier. Her staar endnu meget tilbage. Men jo mere de syge og lægerne opdrages i denne retning, des mere velsignelsesrig vil sanatoriernes virksomhed blive, des flere vil gaa herfra med fuld helse.

(...)

Sanatoriet her paa Harastølen saavelsom paa Reknes modtager syge fra det hele land, men beliggenheden vil selvfølgelig medføre, at Vestlandet og særlig de bergenhusiske amter fornemmelig vil nyde godt af dette sanatorium. Naar nu Vestlandet ved omstændighedernes medfør har opnaat at faa de to første sanatorier inden sin midte, vil vi haabe, at heri vil ligge en særlig opfordring for befolkningen her vesterpaa til at gaa i spidsen i kampen. Vi bor i et land,

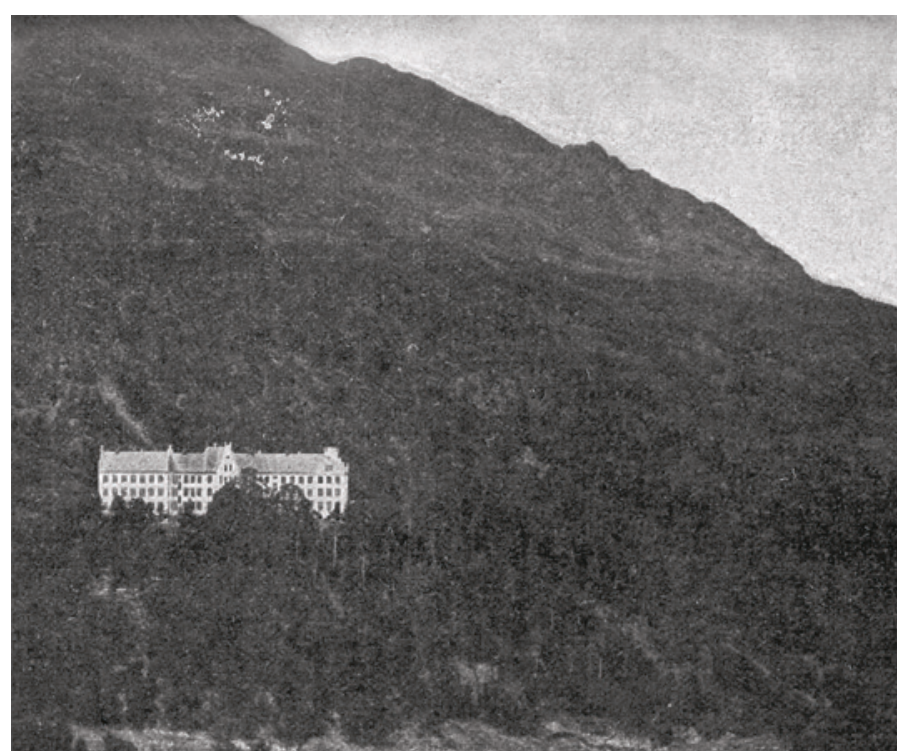

særlig her vesterpaa, i et land med bratte overgange. - Deroppe ligger Fanaraaken med sin evige sne, - dernede ligger Lyster-bygden med sin næsten tropiske plantekultur. Og folket er som landet, et radikalt folk med bratte overgange. Askeladden er vor nationaltype. Endnu ligger vi i asken og roder; - vor hele kultur i retning af renlighed bærer vidne om det. Det er mit haap, at sanatoriet her skal være en drivfjær for Askeladden til at tage et braatak, kaste maren, som magtstjæler vort folk, og i sit levesæt

«rette det som rangt er,

byggja og bøta med bot som duger»

saa en ny sund og kraftig slegt kan følge efter denne, en slegt, som ikke længer har brug for mange sanatorier. 